\title{
Odorants Differentially Enhance Phosphoinositide Turnover and Adenylyl Cyclase in Olfactory Receptor Neuronal Cultures
}

\author{
Gabriele V. Ronnett, ${ }^{1,2}$ Helen Cho, ${ }^{1}$ Lynda D. Hester, ${ }^{1}$ Susan F. Wood, ${ }^{1}$ and Solomon H. Snyder ${ }^{1,3}$ \\ Departments of ${ }^{1}$ Neuroscience, Pharmacology and Molecular Sciences, ${ }^{2}$ Neurology, and ${ }^{3}$ Psychiatry and Behavioral \\ Sciences, Johns Hopkins Medical Institutions, Baltimore, Maryland 21205
}

\begin{abstract}
Both the CAMP and the phosphoinositide (PI) second messenger systems have been implicated in olfactory signal transduction. We have developed a primary culture system of mammalian olfactory receptor neurons (ORNs; Ronnett et al., 1991a) to permit analysis of odorant-induced second messenger system activation in the intact ORN. The ability of a series of odorants to stimulate PI turnover and adenylyl cyclase was examined. All odorants stimulated both second messenger systems, although with differential potencies. Stimulation of PI turnover desensitized upon reexposure of cultures to odorant. The enhancement by single odorants of both adenylyl cyclase and PI turnover, but to varying degrees, affords a mechanism for increased specificity in olfactory signal transduction.

[Key words: phosphoinositide turnover, odorants, odorant receptors, olfactory neurons, adenylyl cyclase, CAMP, inositol 1,4,5-triphosphate $\left(\right.$ Ins $\left.\left.P_{3}\right)\right]$
\end{abstract}

Olfactory signal transduction, which occurs in the cilia of the olfactory receptor neurons (ORNs), involves the generation of the intracellular second messengers cAMP (Pace et al., 1985; Sklar et al., 1986; Breer et al., 1990; Ronnett et al., 1991b) and inositol 1,4,5-trisphosphate (InsP $_{3}$; Boekhoff et al., 1990; Restrepo et al., 1990). The membrane receptors presumed to transduce the odorant stimuli are thought to be G-protein-linked receptors that are members of a large multigene family (Buck and Axel, 1991), although to date there has been no functional evidence that thesc reccptors are odorant receptors. The localization of the two signal transduction pathways in individual sensory neurons is unknown, but recent evidence (Cunningham et al., 1992) suggests that components of both transduction pathways are coexpressed homogeneously across the ciliary layer of the olfactory neuroepithelium.

The odorant-stimulated rise in intracellular cAMP is thought to initiate the electrophysiologic response by directly activating a nonspecific cation channel localized in the surface membrane of the olfactory cilia (Dhallan et al., 1990; Ludwig et al., 1990; Firestein et al., 1991). In catfish, odorants may elicit electro-

\footnotetext{
Received July 13, 1992; revised Oct. 9, 1992; accepted Oct. 27, 1992.

This work was supported by U.S. Public Health Service Grant DA-00266, Research Scientist Award DA-00074 to S.H.S.; a grant of International Flavors and Fragrances, a grant of the Keck Foundation; a Johns Hopkins Clinician Scientist Award, a McKnight Scholars Award, the Whitehall Foundation, and U.S. Public Health Service Grant NS-02131 to G.V.R.

Correspondence should be addressed to Solomon H. Snyder, M.D., The Johns Hopkins University School of Medicine, Department of Neuroscience, 725 North Wolfe Street, Baltimore, MD 21205.

Copyright (C) 1993 Society for Neuroscience $0270-6474 / 93 / 131751-08 \$ 05.00 / 0$
}

physiologic response by gating a $\mathrm{Ca}^{2+}$ channel (Restrepo et al., 1990), but direct evidence for this is lacking in mammalian systems. The potential for cross talk of second messenger cascades exists, as the odorant-induced activation of adenylyl cyclase (AC) in primary cultures of olfactory receptor neurons appears to be $\mathrm{Ca}^{2+}$-dependent (Ronnett et al., 1991b).

To characterize molecular aspects of olfactory signal transduction in detail, we have developed an ORN primary culture system from neonatal rats (Ronnett et al., 1991a). These cells express a mature ORN phenotype, expressing the proteins found in mature ORNs. These cells are bipolar, extending asymmetric processes, one of which is long and unbranched expressing growth-associated protein (GAP)-43, while the other is short and branched and expresses putative odorant receptors and other signal transduction proteins (Cunningham et al., 1991). In this system, we have demonstrated enhancement of AC activity by low nanomolar concentrations of some odorants and have also demonstrated desensitization to odorants (Ronnett et al., $1991 \mathrm{~b})$. In this study we now show augmentation of PI turnover by odorants with concentration-response properties differing from those observed for $\mathrm{AC}$. We also demonstrate that the odorant-induced activation of PI turnover desensitizes.

\section{Materials and Methods}

Primary culture of olfactory neurons. Cultures were prepared as previously described (Ronnett et al., 1991b). Approximately eight litters were used per preparation. The 2-3-d-old rat pups were decapitated and olfactory tissue was dissected and immediately placed in modified Eagle's medium (MEM) containing $4.8 \mathrm{gm} /$ liter of HEPES buffer, $\mathrm{pH} 7.4$, designated MEM-AIR. The turbinates were transferred twice through fresh MEM-AIR to minimize contamination and centrifuged at $700 \times$ $g$ for $7 \mathrm{~min}$. After the supernatant was decanted, the tissue was minced to achieve fragments of approximately $1 \mathrm{~mm}$, resuspended in MEMAIR, and centrifuged at $700 \times g$ for $7 \mathrm{~min}$. Tissue was then placed in $30 \mathrm{ml}$ of MEM-AIR containing $1 \%(\mathrm{w} / \mathrm{v}) \mathrm{BSA}$, radioimmunoassay (RIA) grade (Sigma, St. Louis, MO), $1 \mathrm{mg} / \mathrm{ml}$ hyaluronidase (Sigma), $50 \mu \mathrm{g} /$ $\mathrm{ml}$ DNase (Sigma), $2 \mathrm{mg} / \mathrm{ml}$ collagenase (Worthington Biochemicals, Freehold, NJ), and $5 \mathrm{mg} / \mathrm{ml}$ dispase (Boehringer-Mannheim Biochemicals, Indianapolis, IN), and incubated with agitation for $1 \mathrm{hr}$ at $37^{\circ} \mathrm{C}$. At the end of incubation, the cell suspension was triturated ten times with a $10 \mathrm{ml}$ plastic pipette and passed through a $150 \mu \mathrm{m}$ wire mesh. The cell suspension was then centrifuged at $500 \times g$ for $5 \mathrm{~min}$. The supernatant was aspirated and the cell pellet resuspended in plating medium composed of MEM containing D-valine (MDV; GIBCO, Grand Island, $N Y$ ) containing $15 \%(\mathrm{v} / \mathrm{v})$ dialyzed fetal calf serum (dFCS; GIB$\mathrm{CO}), 5 \%(\mathrm{v} / \mathrm{v})$ NU serum (Collaborative Research, Bedford, MA), 10 $\mu \mathrm{M}$ cytosine arabinoside (ara C), and $25 \mathrm{ng} / \mathrm{ml}$ nerve growth factor (NGF; Collaborative Research). After resuspension, cells were successively filtered through $50 \mu \mathrm{m}$ and $10 \mu \mathrm{m}$ nylon mesh filters (Small Parts, Miami, FL), to remove any remaining undigested clumps of cells and epithelial cells. Cells were plated at a density of $1 \times 10^{6} \mathrm{cells} / \mathrm{cm}^{2}$ into tissue culture dishes (Falcon, Lincoln Park, NJ) or Labtek tissue culture slides 


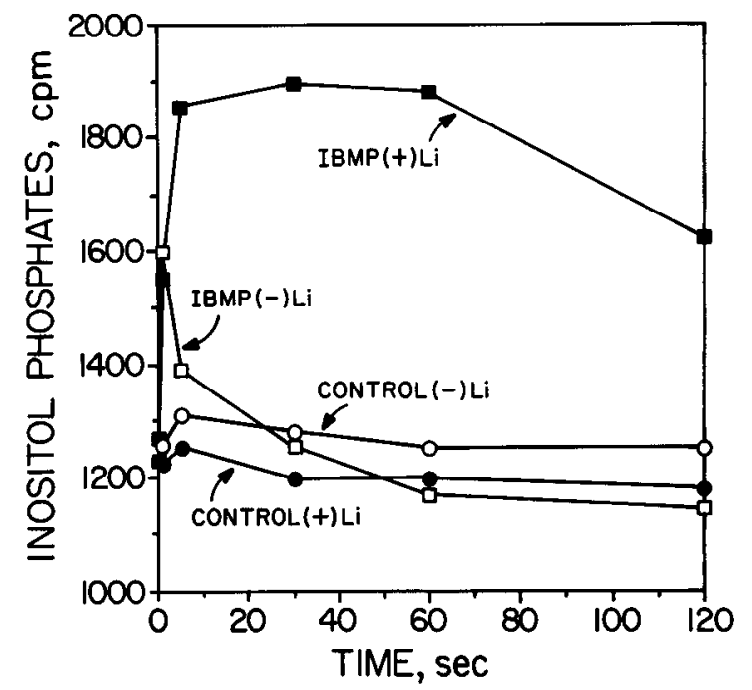

Figure 1. Time course for inositol phosphate production in response to odorant exposure in primary ORN culture. Primary cultures of ORNs were prepared and plated as described in Materials and Methods. Cell monolayers previously metabolically labeled with ${ }^{3} \mathrm{H}$-myo-inositol were exposed to odorants over the time indicated and the reaction quenched with TCA. The production of inositol phosphates was quantitated chromatographically and presented as the sum of $\operatorname{Ins} P_{1}, \operatorname{InsP}_{2}$, and $\operatorname{InsP}_{3}$ formed at each time. Data are expressed as the average of duplicates representative of three separate determinations.

(Nunc, Naperville, IL) coated with MDV containing laminin at $25 \mu \mathrm{g} /$ $\mathrm{ml}$ (Collaborative Research). Cultures were placed in a humidified $37^{\circ} \mathrm{C}$ incubator receiving $5 \% \mathrm{CO}_{2}$. On day 2 and every day thereafter, cells were fed with MDV containing $15 \%$ dFCS, gentamicin, kanamycin, NGF, and ara $C$.

Measurement of PI turnover. The production of inositol phosphates was measured under basal or odorant-stimulated conditions in primary cultures of ORNs maintained in culture for 5-7 d. Assays were performed in cells plated at a density of $1 \times 10^{6} \mathrm{cells} / \mathrm{cm}^{2}$ in 24 -well cluster dishes. Twenty-four hours before use, cells were metabolically labeled with $\left[2-{ }^{-3} \mathrm{H}(\mathrm{N})\right]$-myo-inositol with specific activity of $10-20 \mathrm{Ci} / \mathrm{mmol}$ [New England Nuclear (NEN)-DuPont, Boston, MA]. After 18-24 hr, by which time the cells have reached isotopic equilibrium, the normal feeding medium was replaced with $0.25 \mathrm{ml}$ of MEM-AIR containing $10 \mathrm{mM} \mathrm{LiCl}$ for $1 \mathrm{~min}$. At zero time, $0.25 \mathrm{ml}$ of MEM-AIR containing twice the final concentration of stimulant or odorant was added to each well. The reaction was terminated at times from 0 sec to 2 min by the addition of $0.25 \mathrm{ml}$ of $15 \%(\mathrm{w} / \mathrm{v})$ trichloroacetic acid (TCA). Medium and cells were scraped into microfuge tubes and spun for $1 \mathrm{~min}$. Seven hundred microliters of supernatant were transferred into $12 \times 75$ glass tubes and $1 \mathrm{ml}$ of deionized distilled water added to bring the total volume to $1.7 \mathrm{ml}$. Ether extraction was performed to remove TCA; the reaction mixture was extracted four times with $4 \mathrm{ml}$ of ether, each time aspirating the top ether layer before adding the next. Samples were allowed to sit overnight at $4^{\circ} \mathrm{C}$ and sample $\mathrm{pH}$ was adjusted to 7.4 with $1 \mathrm{~N} \mathrm{NaOH}$. Inositol phosphates were separated chromatographically as described by Creba et al. (1983).

To demonstrate that the inositol phosphates generated resulted from the activation of phospholipase C (PLC) and metabolism of phosphoinositidyl 4,5-bisphosphate $\left(\mathrm{PIP}_{2}\right)$, changes in $\mathrm{PIP}_{2}$ levels were concomitantly measured in cells exposed to odorants by modification of the methods of Creba and colleagues (Berridge et al., 1983; Creba et al., 1983). Cells were prelabeled with ${ }^{3} \mathrm{H}$-myo-inositol and exposed to odorants as described. In this case, once microfuged, the pellets were resuspended in $1 \mathrm{ml}$ of $5 \%$ TCA and respun for $2 \mathrm{~min}$, and the supernatant was discarded. Pellets were resuspended with $1 \mathrm{ml}$ of $1 \mathrm{mM}$ EDTA in deionized distilled water, $\mathrm{pH} 7.5$, and transferred to $13 \times 100 \mathrm{~mm}$ glass tubes. Thereafter, $1.5 \mathrm{ml}$ of a chloroform : methanol : $12 \mathrm{~N} \mathrm{HCl} \mathrm{(100:}$ 100:1) mixture was added to each tube and vortexed. The upper chloroform phase and interface were removed and added to an additional $1.5 \mathrm{ml}$ of the chloroform : methanol: $12 \mathrm{~N} \mathrm{HCl}$ mixture and vortexed. This was repeated a total of three times and the chloroform extracts pooled. Thereafter, $1.5 \mathrm{ml}$ of chloroform and $1.1 \mathrm{ml}$ of $0.1 \mathrm{~N} \mathrm{HCl}$ were added to each tube, vortexed, and the upper phase was removed without disruption of lower phase. This step was repeated, and the lower phase was transferred to $20 \mathrm{ml}$ plastic scintillation vials and dried to evaporation. Scintillation fluor was added and samples counted.

$A C$ assay in $\alpha$-toxin-treated $O R N$ cultures. To assess most accurately the effect of odorant stimulation upon AC activity, a method was developed for the in situ assay of AC activities in ORN monolayers (Ronnett et al., 1991b). ORNs were plated in 24-well cluster dishes at a density of $1 \times 10^{6} \mathrm{cells} / \mathrm{cm}^{2}$. Before experimentation, usually after 5$7 \mathrm{~d}$ in culture, cells were permeabilized with $\alpha$-toxin (Bernheimer, 1968). The feeding medium in each well was replaced with $0.25 \mathrm{ml}$ of intracellular buffer (ICB) containing $150 \mathrm{~mm} \mathrm{KCl}, 20 \mathrm{~mm}$ Tris- $\mathrm{HCl}, 1 \mathrm{~mm}$ $\mathrm{MgCl}_{2}, \mathrm{pH} 7.4$, and buffered free $\mathrm{Ca}^{2+}$ as measured by $\mathrm{Ca}^{2+}$ electrode to be 5-10 $\mu \mathrm{M}$ free $\mathrm{Ca}^{2+}$. The $\alpha$-toxin concentration was $100 \mathrm{U}$ per milliliter of ICB; this amount of $\alpha$-toxin has been titrated to permeabilize greater than $98 \%$ of the cells while allowing no efflux of lactate dehydrogenase activity from these cells (G. V. Ronnett, H. Cho, L. D. Hester, S. F. Wood, and S. H. Snyder, unpublished observation). Preincubation with $\alpha$-toxin is performed for $30 \mathrm{~min}$, at which time cell monolayers are ready for experimentation.

Cell monolayers that had preivously received $0.25 \mathrm{ml}$ of ICB containing $\alpha$-toxin received $0.25 \mathrm{ml}$ of ICB with or without various concentrations of odorants or other stimulants. At intervals from 0-60 sec thereafter, or as dictated by individual protocol, the medium was aspirated and replaced with ICB containing $5 \mathrm{~mm}$ magnesium acetate, $100 \mu \mathrm{M}$ ATP, $100 \mu \mathrm{M}$ GTP, $500 \mu \mathrm{M}$ CAMP, $1 \mathrm{~mm}$ dithiothreitol, $2 \mathrm{mg} /$ $\mathrm{ml}$ phosphocreatine, $500 \mathrm{U} / \mathrm{ml}$ creatine phosphokinase, and ${ }^{32} \mathrm{P}$-ATP (NEN-DuPont, Boston, MA). After $15 \mathrm{sec}$, the reaction was stopped with quench containing ATP $(20 \mathrm{mg} / \mathrm{ml}), 2 \%(\mathrm{w} / \mathrm{v})$ sodium dodecylsulfate, and $1.3 \mathrm{mM}$ cAMP. ${ }^{3} \mathrm{H}$-cAMP was used as a tracer in the stop solution to calculate recoveries. Cell monolayers were then scraped and cellular material processed as previously described by Salomon (1979). Using this methodology, conversion of ${ }^{32} \mathrm{P}$-ATP into labeled cAMP is linear for at least $15 \mathrm{~min}$ and is stimulated by GTP- $\gamma-\mathrm{S}$ (suggesting that G-protein coupling is maintained) and forskolin (Ronnett et al., 1991b).

Cilia preparation. Rat olfactory cilia were prepared as previously described (Sklar et al., 1986). Briefly, male Sprague-Dawley rats were killed by decapitation. Nasal turbinates were dissected, pooled, and washed in Kreb's-Ringer's solution ( $120 \mathrm{~mm} \mathrm{NaCl}, 5 \mathrm{mM} \mathrm{KCl}, 1.6 \mathrm{~mm}$ $\mathrm{K}_{2} \mathrm{HPO}_{4}, 25 \mathrm{~mm} \mathrm{NaHCO}, 7.4 \mathrm{~mm}$ glucose, $\mathrm{pH} 8.0$ ) at $4^{\circ} \mathrm{C}$. The tissue was centrifuged at $1000 \times \mathrm{g}$ for $5 \mathrm{~min}$. The pellet was resuspended in $100 \mathrm{~mm}$ Tris- $\mathrm{HCl}, \mathrm{pH} 8.0$. The bathing medium was supplemented with $\mathrm{CaCl}_{2}$ to a final concentration of $10 \mathrm{~mm}$ and agitated gently on an endover-end shaker for $20 \mathrm{~min}$ at $4^{\circ} \mathrm{C}$. The deciliated epithelium was removed by centrifugation for $5 \mathrm{~min}$ at $6000 \times \mathrm{g}$. The supernatant containing the detached cilia was centrifuged for $10 \mathrm{~min}$ at $12,000 \times \mathrm{g}$ and the resulting pellet containing the isolated cilia was washed twice in 10 mM Tris- $\mathrm{HCl}, 3 \mathrm{~mm} \mathrm{MgCl} 2$, 1 mm EDTA, $\mathrm{pH} \mathrm{8.0.} \mathrm{The} \mathrm{final} \mathrm{cilia} \mathrm{pellet}$ was resuspended in a small volume of $10 \mathrm{~mm}$ Tris- $\mathrm{HCl}, 3 \mathrm{mM} \mathrm{MgCl}$, 1 mM EDTA, pH 8.0.

The concentrated rat cilia were aliquoted and stored at $-70^{\circ} \mathrm{C}$. No loss of activity was detected for up to six months. Protein concentrations of the final cilia preparations were measured according to the method of Lowry et al. (1951) using bovine serum albumin as standard.

\section{Results}

\section{Time course for stimulation of PI turnover by odorant}

To determine initially the ability of odorants to stimulate PI turnover in primary cultures of ORNs, cell monolayers were exposed to $0.1 \mu \mathrm{M}$ 3-isobutyl-2-methoxypyrazine (IBMP) in the presence or absence of $10 \mathrm{~mm} \mathrm{LiCl}$ (which inhibits the inositol 1-monophosphatase) as described in Materials and Methods. The reaction was quenched at various times, from 0 to $120 \mathrm{sec}$ after initial exposure, and cellular material processed as described. As shown in Figure 1, exposure of cells to low levels of IBMP causes a rapid, transient increase in production of inositol phosphates that peaks by $1 \mathrm{sec}$ and diminishes rapidly thereafter. In the presence of $\mathrm{LiCl}$, the absolute amount of inositol phosphates that accumulates is enhanced, due to the decreased degradation of inositol 1-monophosphate and the higher phosphorylated inositol phosphates. Control monolayers ex- 


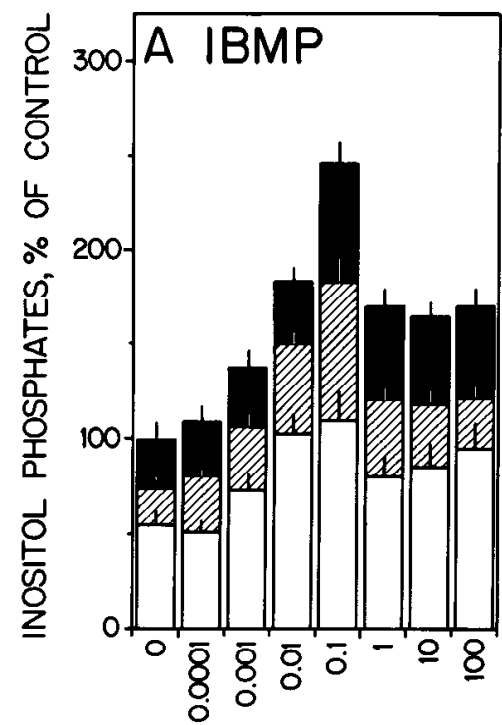

$[\mathrm{IBMP}], \mu \mathrm{M}$

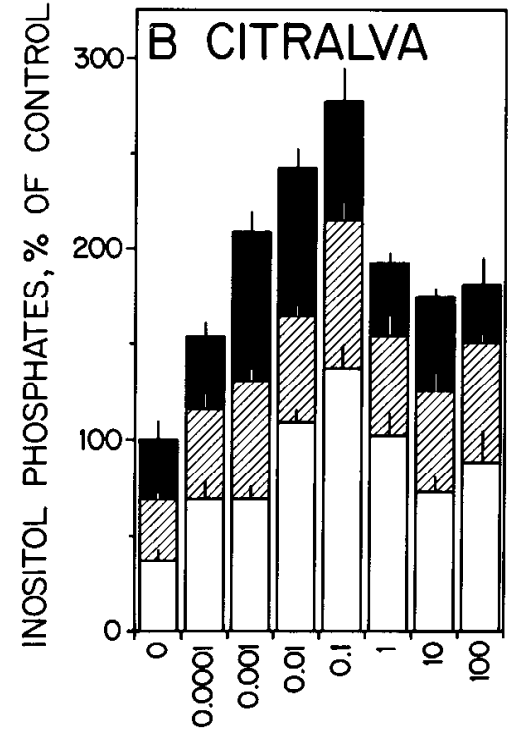

[CITRALVA], $\mu \mathrm{M}$

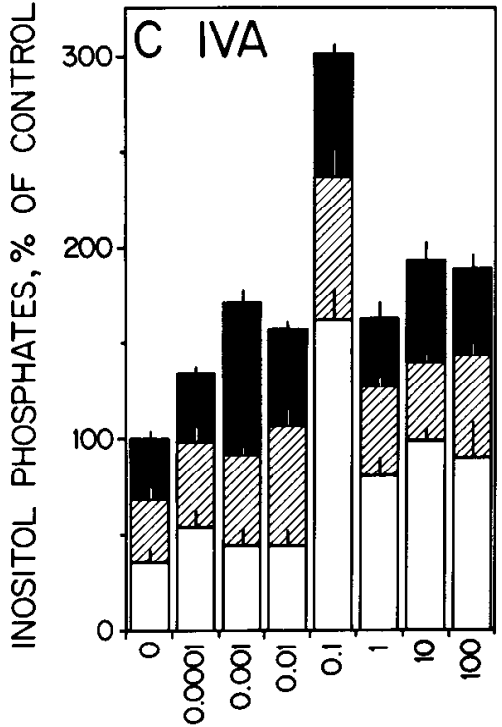

[IVA], $\mu \mathrm{M}$
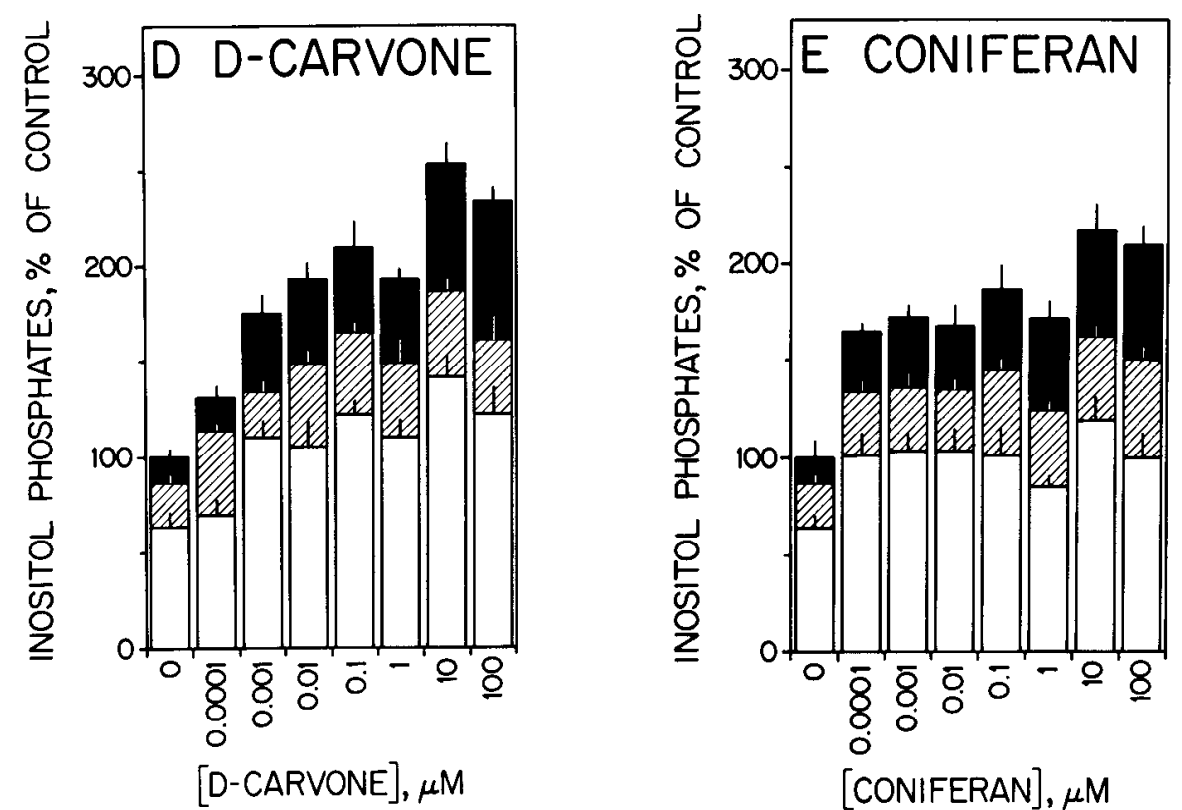

Figure 2. Effect of odorants on inositol phosphate production in ORN cultures. Primary cultures of ORNs were metabolically labeled with ${ }^{3} \mathrm{H}-$ myo-inositol. Monolayers were pre-incubated for $1 \mathrm{~min}$ with $10 \mathrm{mM} \mathrm{LiCl}$ and at zero time were exposed to medium containing odorants at the designated concentrations. Incubation was terminated at $5 \mathrm{sec}$, and the amounts of inositol phosphates Ins $\mathrm{P}_{1}$ (open bars), Ins $\mathrm{P}_{2}$ (hatched bars), and $\mathrm{InsP}_{3}$ (solid bars) were determined. Enhancement of PI turnover occurs for all odorants, although potencies and overall level of stimulation vary. Odorants examined were IBMP $(A)$, citralva $(B)$, IVA $(C)$, D-carvone $(D)$, and coniferan $(E)$. Results are shown as means \pm SEM for at least three independent determinations.

posed to the same medium changes in the presence or absence of Li demonstrate no significant change in production of inositol phosphates. Based upon these results, subsequent experiments were performed by preincubation of cells for $1 \mathrm{~min}$ with $10 \mathrm{mM}$ $\mathrm{LiCl}$ and exposure of cell monolayers to odorants at the various concentrations for $5-10 \mathrm{sec}$ before the reactions were stopped.

\section{Odorants enhance PI turnover}

To determine whether enhancement of PI turnover occurs with exposure to a number of odorants, the production of inositol phosphates was monitored for several odorants at various concentrations. PI turnover in primary cultures of ORNs was monitored by incubations of cells with ${ }^{3} \mathrm{H}$-myo-inositol followed by quantification of levels of the ${ }^{3} \mathrm{H}$-inositol phosphates, ${ }^{3} \mathrm{H}$-inositol 1-monophosphate (InsP $\left.\mathrm{P}_{1}\right),{ }^{3} \mathrm{H}$-inositol 1,4-bisphosphate (InsP $\mathrm{P}_{2}$ ), and ${ }^{3} \mathrm{H}$-inositol 1,4,5-trisphosphate (InsP $\mathrm{P}_{3}$ ) (Fig. 2). We examined influences of the malodor isovaleric acid (IVA) as well as odorants not regarded as malodors, such as citralva, D-carvone, IBMP, and coniferan. Earlier, Sklar et al. (1986) found that pleasant odorants enhanced $\mathrm{AC}$ while putrid odor- 


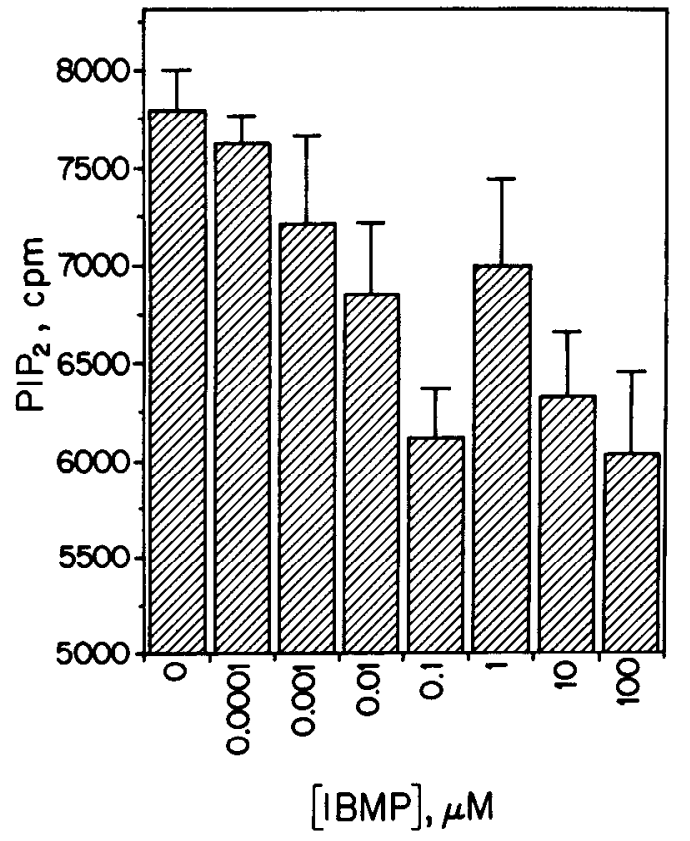

Figure 3. Effect of IBMP on $\mathrm{PIP}_{2}$ levels in ORN cultures. Cultures were prelabeled with ${ }^{3} \mathrm{H}$-myo-inositol, preincubated with $10 \mathrm{~mm} \mathrm{LiCl}$ for $1 \mathrm{~min}$, and exposed to IBMP $(0-100 \mu \mathrm{M})$, and the reaction was terminated after 5 sec. The absolute amount of ${ }^{3} \mathrm{H}$-PIP, remaining in the culture was quantitated. Exposure to IBMP results in a dose-dependent depletion of ${ }^{3} \mathrm{H}-\mathrm{PIP}_{2}$ that corresponds to the formation of ${ }^{3} \mathrm{H}$ inositol phosphates. Results are expressed as mean $\pm \operatorname{SEM}(n=3)$.

ants were without effect. Breer and associates (Boekhoff et al., 1990; Breer et al., 1990) also reported that pleasant but not putrid odorants enhanced cAMP levels in olfactory cilia, while only putrid odorants stimulated InsP ${ }_{3}$ levels. By contrast, we observe enhancement of PI turnover for all odorants examined (Fig. 2), although the absolute level of stimulation varies significantly for each odorant. As little as $0.1 \mathrm{~nm}$ IVA (Fig. $2 C$ ) significantly augments PI turnover, while maximal responses occur at $0.1 \mu \mathrm{M}$, with a tripling of turnover. Higher concentrations of odorants produce less of an effect than peak levels obtained at $0.1 \mu \mathrm{M}$. Citralva is also potent, producing a $50 \%$ enhancement of PI turnover at $0.1 \mathrm{nM}$, maximal effects of almost threefold at $0.1 \mu \mathrm{M}$, with lesser responses at higher concentrations (Fig. 2B). D-Carvone also augments PI turnover at $0.1 \mathrm{~nm}$ with more than a doubling at $0.1 \mu \mathrm{M}$ (Fig. $2 D$ ). Unlike IVA and citralva, D-carvone effects do not seem to diminish at higher concentrations. IBMP, the most potent odorant examined in terms of effects on $\mathrm{AC}$, is somewhat less potent than other odorants in stimulating PI turnover (Fig. $2 A$ ). Significant enhancement is observed at $1.0 \mathrm{nM}$, with a maximal $230 \%$ stimulation at $0.1 \mu \mathrm{M}$ and lesser effects at higher concentrations. Coniferan significantly enhances PI turnover at $0.1 \mathrm{nM}$, similar in potency to the other odorants examined (Fig. $2 E$ ). However, its maximal effect on PI turnover is less than for the other odorants, with a maximal stimulation of about twofold.

To ensure that the generation of ${ }^{3} \mathrm{H}$-inositol phosphates reflects hydrolysis of their precursor $\mathrm{PIP}_{2}$, we monitored levels of ${ }^{3} \mathrm{H}-\mathrm{PIP}_{2}$ in response to different concentrations of IBMP (Fig. 3). As little as $1 \mathrm{~nm}$ IBMP significantly reduces levels of ${ }^{3} \mathrm{H}$ $\mathrm{PIP}_{2}$, with maximal reduction at $0.1 \mu \mathrm{M}$, corresponding to the concentration that produces maximal enhancement of ${ }^{3} \mathrm{H}$-inositol phosphate production. At $1 \mu \mathrm{M}$ IBMP, a lesser reduction in ${ }^{3} \mathrm{H}-\mathrm{PIP}{ }_{2}$ is observed than at $0.1 \mu \mathrm{M}$, corresponding to effects observed on ${ }^{3} \mathrm{H}$-inositol phosphates.

\section{Desensitization to odorant effects on PI turnover in ORN cultures}

To evaluate desensitization, we exposed cultures to odorants for $60 \mathrm{sec}$ and then replaced the medium with odorant-free medium and reapplied odorants after another $15 \mathrm{sec}$ (Fig. 4). Desensitization to all five odorants is seen. At all concentrations of odorants examined, enhancement of PI turnover is abolished upon the second application of odorants. Most notably, for several of the odorants PI turnover is markedly depressed upon the second stimulation, as is most evident with IBMP (Fig. 4A). At $0.1 \mathrm{nM}$ initial exposure, IBMP fails to stimulate PI turnover significantly, while a second exposure reduces basal PI turnover about $60 \%$. A similar reduction of PI turnover is evident upon second exposure to all concentrations of IBMP. A reduction of PI turnover on second exposure is observed with most concentrations of coniferan $(E)$ and D-carvone $(D)$, while such effects are less evident with IVA $(C)$ and citralva $(B)$.

To demonstrate that the lack of further response upon reexposure to odorant reflects desensitization, the reversibility of this effect was investigated (Fig. 5). Cell monolayers were prelabeled with ${ }^{3} \mathrm{H}$-myo-inositol as described. At zero time, monolayers were exposed to control medium or medium containing $0.1 \mu \mathrm{M}$ IBMP for $15 \mathrm{sec}$, at which time monolayers were rinsed and the incubation continued in the absence of odorants. At 1 min, some monolayers were reexposed to odorants to determine the effect of a second acute exposure on odorant-induced PI turnover. Incubation was continued for other monolayers in the absence of odorants for several minutes, at which time reexposure to $0.1 \mu \mathrm{M}$ IBMP occurred. Upon initial exposure to odorant, there is a pronounced rise in inositol phosphate production, while reexposure after a short time does not result in augmentation of PI turnover (Fig. 5). However, after several minutes, cells are again responsive, with odorant causing an increase in inositol phosphate production. Thus, this effect appears reversible.

\section{Odorants differ in effects on $A C$ and PI turnover}

In a previous study we demonstrated enhancement of $A C$ by odorants in ORN cultures, but examined detailed concentration-response relationships only for IBMP (Ronnett et al., 1991b). To compare odorant effects upon AC and PI turnover, we have carried out concentration-response studies with the five odorants evaluated for PI turnover (Fig. 6). As previously observed, IBMP is extraordinarily potent, more than doubling $\mathrm{AC}$ at $0.1 \mathrm{~nm}$ and producing a maximal eightfold increase in activity at $0.1 \mu \mathrm{M}$, after which a decrease in response occurs at higher IBMP concentrations (Fig. 6A). This response contrasts with the weaker effects of IBMP on PI turnover with significant enhancement evident only at $1.0 \mathrm{~nm}$ (Table 1).

By contrast, IVA is much weaker in stimulating AC than in augmenting PI turnover (Fig. $6 \mathrm{C}$ ). Whereas $0.1 \mathrm{~nm}$ IVA increases PI turnover, $10 \mathrm{nM}$ is required to enhance $\mathrm{AC}$ signifcantly. Similarly, D-carvone $(D)$ and coniferan $(E)$ significantly augment PI turnover at $0.1 \mathrm{~nm}$ but do not produce significant effects on AC till $10 \mathrm{~nm}$. Citralva $(B)$ produces significant increases in $\mathrm{AC}$ at $1 \mathrm{~nm}$ and significantly increases PI turnover at $0.1 \mathrm{~nm}$.

For most odorants, maximal stimulation of $\mathrm{AC}$ is greater than for PI turnover. However, the pattern is reversed for D-carvone 

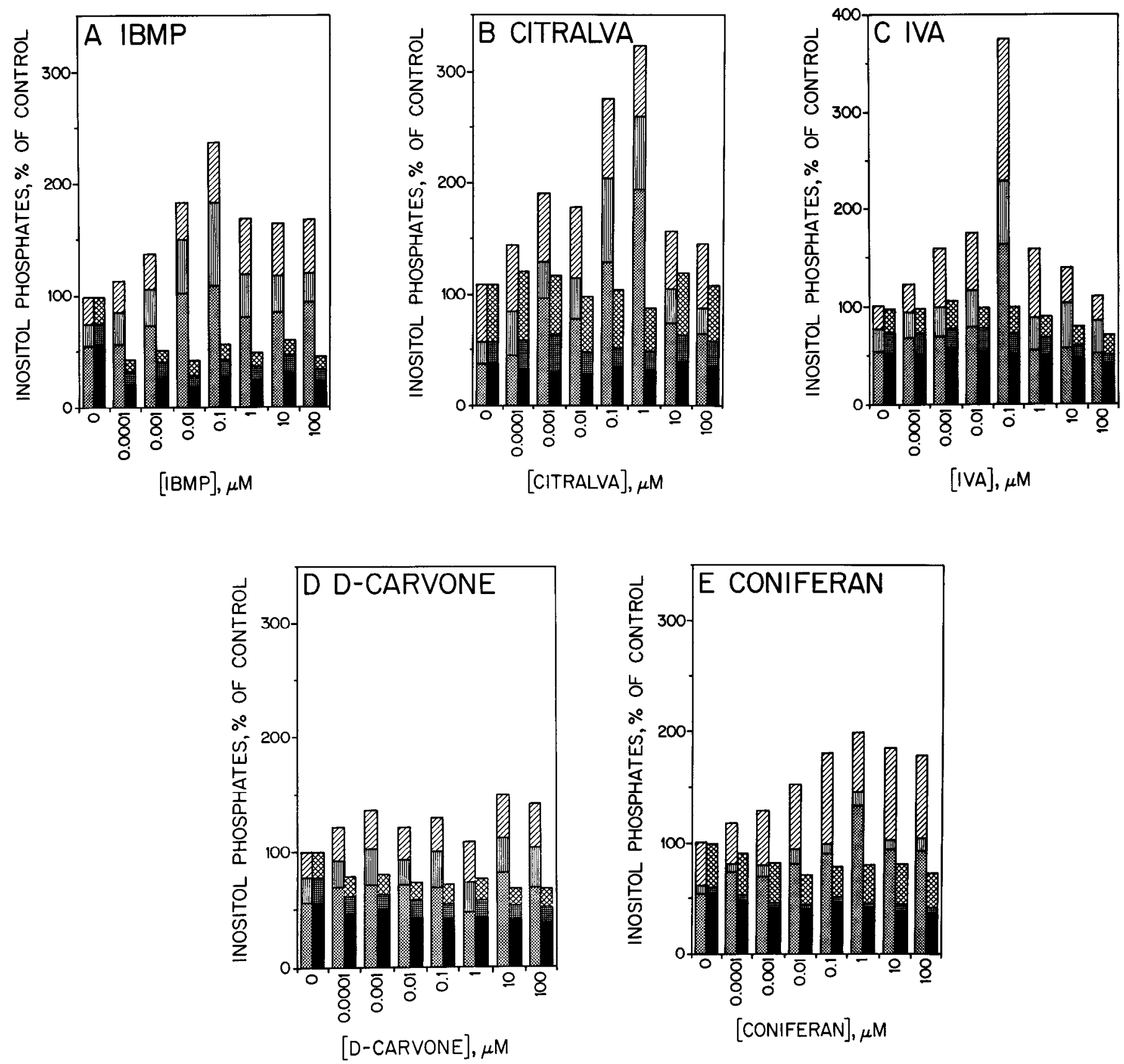

Figure 4. Desensitization of odorant-induced effects on PI turnover. Cultures were metabolically labeled with ${ }^{3} \mathrm{H}-\mathrm{myo}$-inositol. Duplicate cultures were exposed to each odorant at the designated concentrations for 5 sec (when the reaction was terminated and the level of inositol phosphates determined) or $60 \mathrm{sec}$ when medium was withdrawn and replaced with odorant-free medium for $15 \mathrm{sec}$. This second exposure was allowed to continue for $5 \mathrm{sec}$, and then the reaction was quenched as described in Materials and Methods. Inositol phosphate production following initial exposure to odorants ( first bar in each set) or reexposure (second bar in each set) was determined for IBMP $(A)$, citralva (B), IVA (C), D-carvone $(D)$, and coniferan $(E)$. Results are shown for $\operatorname{InsP}_{1}$ (dotted bars), InsP $\mathrm{P}_{2}$ (vertical-hatched bars), and InsP ${ }_{3}$ (diagonal-hatched bars) produced upon initial exposure and for Ins $\mathrm{P}_{1}$ (solid bars), Ins $\mathrm{P}_{2}$ (small-crosshatched bars), and $\mathrm{InsP}_{3}$ (large-crosshatched bars) formed upon reexposure to odorants. For all odorants examined, enhancement of PI turnover is abolished upon the second application of odorants. Additionally, and most notably for IBMP, PI turnover is markedly depressed upon the second stimulation. Results are expressed as averages representative of three determinations.

and coniferan, which produce a greater maximal augmentation of PI turnover than of $\mathrm{AC}$, in striking contrast to IBMP and citralva, which produce severalfold greater maximal increase in AC than PI turnover (Table 1).

A bell-shaped concentration-response curve for odorant effects on $A C$ is most evident with IBMP and citralva, but is seen to some extent with other odorants. This parallels similar bellshaped responses of the odorants on PI turnover. In most in- stances maximal responses are evident at $0.1 \mu \mathrm{M}$, with lesser responses at higher concentrations. Whether lesser responses at high concentrations of odorants reflect desensitization or some other process is unclear.

\section{Discussion}

In this study we demonstrate extraordinarily potent effects of odorants on PI turnover and AC. These influences fit with the 


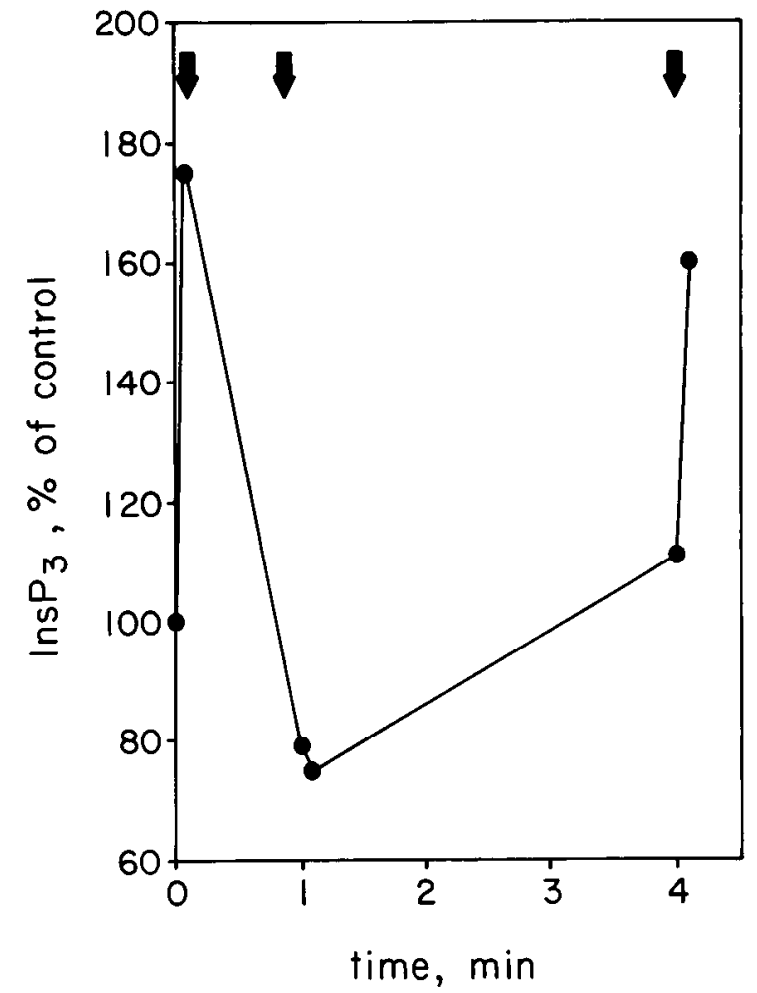

Figure 5. Resensitization of PI turnover to odorants. Cultures were metabolically labeled with ${ }^{3} \mathrm{H}$-myo-inositol. At zero time, cultures were exposed to $0.1 \mu \mathrm{M}$ IBMP or control medium for $20 \mathrm{sec}$, after which time the medium was removed and replaced with odorant-free medium. At $1 \mathrm{~min}$, monolayers were reexposed to $0.1 \mu \mathrm{M}$ IBMP and the effect of odorant on PI turnover was again measured. Duplicate monolayers were allowed to continue in an odorant-free medium and reexposed to odorants after $3 \mathrm{~min}$, at which time dupliciate monolayers were again exposed to $0.1 \mu \mathrm{M}$ IBMP and assayed for InsP $\mathrm{P}_{3}$ production. Exposure to odorant is noted by arrows. For all points, control monolayers that received mock medium changes were assayed to determine the amount of ${ }^{3} \mathrm{H}$-InsP $\mathrm{P}_{3}$ under controlled conditions. Results are reported as amount of ${ }^{3} \mathrm{H}$-Ins $\mathrm{P}_{3}$ present relative to control. Results are expressed as averages representative of three independent determinations.

known psychophysical potencies of odorants, with agents such as IBMP being detected in two parts per trillion. Initial studies (Pace et al., 1985; Sklar et al., 1986) of odorant effects on AC required 10-100 $\mu \mathrm{M}$ concentrations to produce substantial effects, almost five orders of magnitude weaker than effects observed in our studies (Ronnett et al., 1991b) as well as those of Breer and associates (Boekhoff et al., 1990; Breer et al., 1990) in olfactory cilia. Earlier studies also did not show correlations between potencies of odorants in stimulating $\mathrm{AC}$ and their psychophysical potencies. The earlier studies used exposures of 15 min or more and may have reflected interactions with desensitized receptors. One of the striking features of the present study is the rapidity of the PI response, with maximal enhancement evident by $1 \mathrm{sec}$ or less after odorant exposure. In cilia utilizing rapid-mix techniques, even more rapid effects of odorants are evident (Boekhoff et al., 1990; Breer et al., 1990).

In ORN cultures utilizing in situ assays, the maximal PI response to odorants is evident in $1 \mathrm{sec}$ and lasts for a few seconds, while AC activation is detectable at $1 \mathrm{sec}$ and is maximal at 10 $15 \mathrm{sec}$, with a rapid decline thereafter. In isolated cilia Breer et al. (1990) observe increases in CAMP and InsP ${ }_{3}$ levels within milliseconds with responses terminated in $0.1-0.2 \mathrm{sec}$. In intact
Table 1. Relative potencies of odorants in stimulating PI turnover and $A C$ activity

\begin{tabular}{llllll} 
& \multicolumn{2}{c}{ Potency $^{a}$} & & \multicolumn{2}{c}{$\begin{array}{l}\text { Fold stimulation } \\
\text { Odover basal }\end{array}$} \\
\cline { 2 - 3 } IBMP & PI & AC & & PI & AC \\
\hline Citralva & 1.0 & 0.1 & & 2.5 & 8 \\
IVA & 0.1 & 1.0 & & 2.8 & 7 \\
D-Carvone & 0.1 & 10 & & 3.0 & 6.1 \\
Coniferan & 0.1 & 10 & & 2.5 & 2.2 \\
& 0.1 & 10 & & 1.2 & 1.9
\end{tabular}

a Potency is expressed as the micromolar concentration of odorant at which statistically significant stimulation of PI turnover or AC activation occurs, so lower values reflect greater potency. This mode of designating potency was employed, as concentrations producing $50 \%$ of maximal responses could not be readily ascertained because of the complex concentration-response relationships. Significant stimulation is defined as significantly different from control levels $(p<0.01)$ when values are analyzed by $t$ test.

${ }^{b}$ Fold stimulation over basal levels of PI turnover and AC activation by odorants is presented as the ratio of maximal stimulation by each odorant to basal levels. The PI and AC data for potency calculations are derived from Figures 2 and 7.

olfactory neurons the depolarizing current in response to odorants is maintained for 7-10 sec (Firestein et al., 1991), resembling the time course of second messenger activation in the olfactory cultures (Ronnett et al., 199 l b). The rapid loss of InsP and cAMP responses in isolated cilia may reflect the loss of metabolic integrity associated with the $\mathrm{Ca}^{2+}$ shocking procedures used to prepare cilia.

We find that all five odorants examined stimulate both PI turnover and AC, whereas Breer et al. (1990) found odorants exclusively influencing one or the other sccond messenger. In their study most odorants were screened at a single $1 \mu \mathrm{M}$ concentration, so effects of odorants at other concentrations might not have been detected. Some of the general patterns we observe resemble those of Breer et al. (1990). For instance, we find that IVA is more potent in stimulating PI turnover than AC, fitting with their data (Breer et al., 1990). In our earlier studies in cilia (Sklar et al., 1986) and in work or Breer's group (Boekhoff et al., 1990; Breer et al., 1990), more pleasant odorants tend to have greater effects on $\mathrm{AC}$ while malodors preferentially stimulate PI turnover. However, there are a number of exceptions to this pattern.

Because we observe different concentration-response relationships for certain odorants in influencing PI turnover and $\mathrm{AC}$, it is likely that such responses involve different receptors or populations of receptors. This conclusion fits with the very large numbers of putative odorant receptors that have been molecularly cloned (Buck and Axel, 1991).

Our data suggest that cross talk may take place between the cAMP and PI messenger systems, as is well characterized for neurotransmitter and hormone effects on second messengers (Bouvier, 1988; Parenti et al., 1989; Klaus and Harnett, 1991; Morris et al., 1991; Kozawa et al., 1992). Because maximal odorant enhancement of PI turnover, both in primary olfactory neuronal cultures and in isolated cilia, precedes maximal stimulation of $A C$, and as odorant enhancement of $A C$ in ORN cultures requires $\mathrm{Ca}^{2+}$, we suggested that $\mathrm{PI}$ turnover may contribute to AC stimulation (Ronnett et al., 1991b). Thus, $\mathrm{Ca}^{2+}$ released by $\mathrm{InsP}_{3}$ might stimulate $\mathrm{AC}$, conclusions supported by our observations that introduction of nonhydrolyzable InsP $\mathrm{P}_{3}$ into $\mathrm{ORN}$ cultures stimulates $\mathrm{AC}$ activity (G. V. Ronnett, unpublished observations). The $\mathrm{Ca}^{2+}$ dependency of the cAMP 


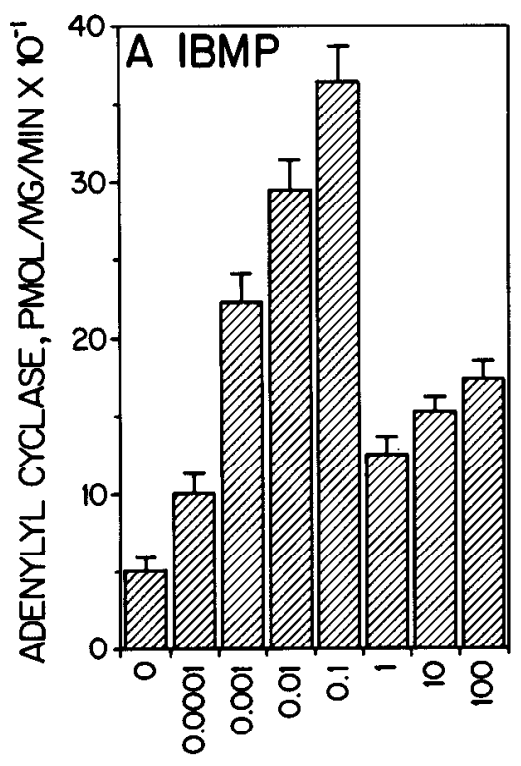

[IBMP], $\mu \mathrm{M}$

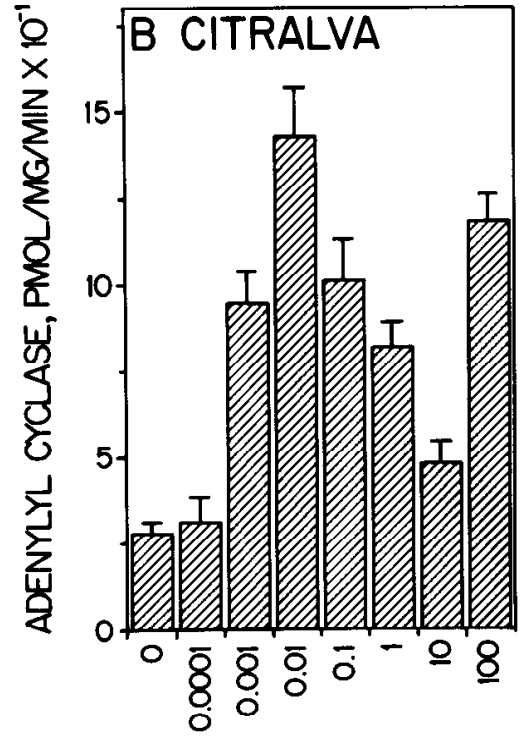

[CITRALVA], $\mu \mathrm{M}$

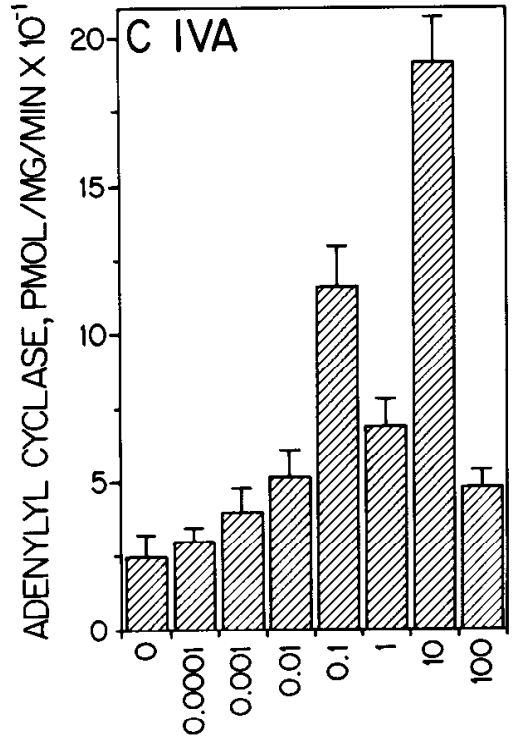

[IVA], $\mu \mathrm{M}$

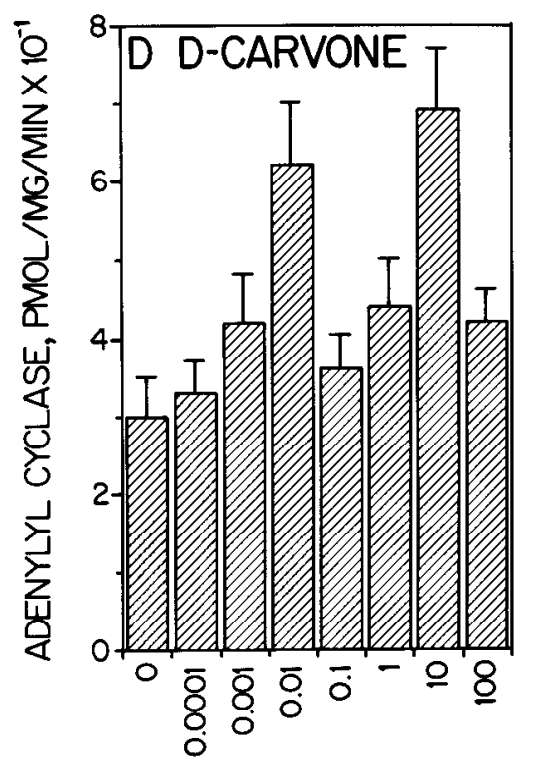

[D-CARVONE], $\mu \mathrm{M}$

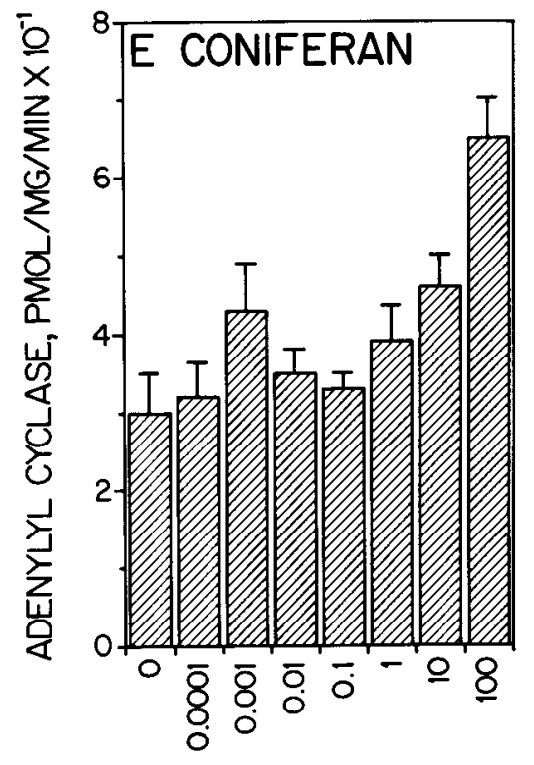

[CONIFERAN], $\mu \mathrm{M}$

Figure 6. Effect of odorants on AC activity in ORN cultures. Cultures were permeabilized with $\alpha$-toxin. At zero time, monolayers were exposed to odorant at the designated concentration for $0-60 \mathrm{sec}$. The odorant was then aspirated and replaced with reaction mixture containing ${ }^{32} \mathrm{P}-\mathrm{ATP}$ and the reaction was allowed to proceed for $15 \mathrm{sec}$, at which time the reaction was quenched and the amount of ${ }^{32} \mathrm{P}$-cAMP determined. Maximal activation occurs with $10-15 \mathrm{sec}$ of odorant stimulation. Odorants tested were IBMP $(A)$, citralva $(B)$, IVA $(C)$, D-carvone $(D)$, and coniferan $(E)$. All odorants examined stimulate $\mathrm{AC}$ activity in a biphasic manner with differing potencies and absolute levels of stimulation. Results are expressed as mean $\pm \operatorname{SEM}(n=3)$.

response in isolated rat cilia may be lost due to the $10 \mathrm{~mm} \mathrm{Ca}^{2+}$ shocking procedure required for isolation of cilia, which may disrupt the cellular response. Though such cross talk between the second messengers is possible, the differences in concentration-response relationships between odorants in influencing PI turnover in $\mathrm{AC}$ indicate that distinct receptor-linked responses may occur for the two systems.

InsP $_{3}$ generated by receptor-mediated stimulation of phospholipase $\mathrm{C}$ is thought to act by mediating the release of $\mathrm{Ca}^{2+}$ from intracellular stores (Berridge and Irvine, 1989; Cunning- ham et al., 1991). There is evidence that a subclass of InsP receptors may exist at the level of ciliary surface membrane (Restrepo et al., 1990; Kalinoski et al., 1992; A. M. Cunningham, D. K. Ryugo, A. H. Sharp, R. R. Reed, G. V. Ronnett, and $\mathrm{S}$. H. Snyder, unpublished observations). The $\operatorname{InsP}_{3}$ generated by interaction of receptive cells with odorants may interact with InsP $_{3}$ receptors contained in ciliary surface membranes and facilitate the entrance of $\mathrm{Ca}^{2+}$ involved in the initial signaling cascade or in desensitization. A number of studies (Getchell, 1986; Nakamura and Gold, 1987; Winegar et al., 
1988; Anholt and Rivers, 1990; Restrepo et al., 1990) have implicated an influx of $\mathrm{Ca}^{2+}$ in olfactory signal transduction both in the generation of the initial signal and in desensitization.

An increase in intracellular $\mathrm{Ca}^{2+}$ may be important for several aspects of signal transduction. For the $\mathrm{AC}$ activity assayed in intact ORN cultures (Ronnett et al., 1991b) and in expression studies of the type III AC, which is thought to be olfactoryspecific, there is an augmentation of enzyme activity by free $\mathrm{Ca}^{2+}$ concentrations in the micromolar range (Bakalyar and Reed, 1991). A number of phosphodiesterases have been characterized and localized to the ORN in the olfactory neural epithelium; at least one of these species is $\mathrm{Ca}^{2+} /$ calmodulin dependent (Borisy et al., 1991). Thus, desensitization may occur through activation of a $\mathrm{Ca}^{2+}$-dependent phosphodiesterase activity. In several nonmammalian species, $\mathrm{Ca}^{2+}$ influx is postulated to result directly in depolarization (Winegar et al., 1988; Leveteau et al., 1989; Restrepo et al., 1990). Others finds that $\mathrm{Ca}^{2+}$ blocks the cyclic nucleotide-gated channel and may therefore function in desensitization (Kurahashi and Shibuya, 1990).

We have observed desensitization occurring quite rapidly to odorant effects on PI turnover, similar to desensitization by odorants to AC observed earlier (Ronnett et al., 1991b). Although the mechanisms of olfactory descnsitization are unclear, there is some evidence for involvement of protein kinase $A$ and protein kinase C (Boekhoff and Breer, 1992). Most notable is the lowering of PI turnover levels to values less than half of basal level. We observe this feature of desensitization with 0.1 nM IBMP, a concentration too low to stimulate PI turnover of itself. Mechanisms responsible for desensitization at this concentration remain unclear, but may be related to a number of factors such as second messenger cross talk.

\section{References}

Anholt RRH, Rivers AM (1990) Olfactory transduction: cross-talk between second-messenger systems. Biochemistry 29:4049-4054.

Bakalyar HA, Reed RR (1991) The second messenger cascade in olfactory receptor neurons. Curr Opin Neurobiol 1:204-208, 284-285.

Bernheimer AW (1968) Cytolytic toxins of bacterial origin. Science 159:847-851.

Berridge MJ, Irvine RF (1989) Inositol phosphates and cell signalling. Nature 341:197-204.

Berridge MJ, Dawson RMC, Downes CP, Heslop JP, Irvine RF (1983) Changes in the levels of inositol phosphates after agonist-dependent hydrolysis of membrane phosphoinositides. Biochem J 212:473-482.

Boekhoff I, Breer H (1992) Termination of second messenger signaling in olfaction. Proc Natl Acad Sci USA 89:471-474.

Boekhoff I, Tareilus E, Strotmann J, Breer H (1990) Rapid activation of alternative second messenger pathways in olfactory cilia from rats by different odorants. EMBO J 9:2453-2458.

Borisy FF, Ronnett GV, Cunningham AM, Juilfs D, Beavo J, Snyder SH (1991) Calcium/calmodulin activated phosphodiesterase selectively expressed in olfactory receptor neurons. J Neurosci 12:915923.

Bouvier M (1988) Cross-talk between second messengers. Ann NY Acad Sci 120-127.

Breer H, Boekhoff I, Tareilus E (1990) Rapid kinetics of second messenger formation in olfactory transduction. Nature 345:65-68.

Buck L, Axel R (1991) A novel multigene family may encode odorant receptors: a molecular basis for odor recognition. Cell 65:175-187.

Creba JA, Downes CP, Hawkins PT, Brewster G, Michell RH, Kirk CJ
(1983) Rapid breakdown of phosphatidylinositol 4-phosphate and phosphatidyl-inositol 4,5-bisphosphate in rat hepatocytes stimulated by vasopressin and other $\mathrm{Ca}^{2+}$-mobilizing hormones. Biochem $\mathrm{J} 212$ : 733-747.

Cunningham AM, Ronnett GV, Manis PB, Reed RR, Snyder SH (1991) Olfactory receptor neurons express components of two distinct second messenger systems. Soc Neurosci Abstr 17:180.

Cunningham AM, Reed RR, Ryugo DK, Snyder SH, Ronnett GV (1992) Inositol-1,4,5-trisphosphate receptor is localized to the ciliary surfacae membrane in olfactory sensory neurons and may mediate odorant-induced signal transduction. Chem Senses, in press.

Dhallan RS, Yau K, Schrader K, Reed R (1990) Primary structure and functional expression of a cyclic nucleotide-activated channel from olfactory neurons. Nature 347:184-187.

Firestein S, Darrow B, Shepherd GM (1991) Activation of the sensory current in salamander olfactory receptor neurons depends on a $G$ protein-mediated cAMP second messenger system. Neuron 6:825835.

Getchell TV (1986) Functional properties of vertebrate olfactory receptor neurons. Physiol Rev 66:772-818.

Kalinoski DL, Aldinger SB, Boyle AG, Huque T, Maracek JF, Prestwich GD, Restrepo D (1992) Characterization of a novel inositol 1,4,5trisphosphate receptor in isolated olfactory cilia. Biochem J 281:449456.

Klaus GGB, Harnett MM (1991) Cross-talk between surface immunoglobin and interleukin- 4 receptors on murine B-lymphocytes. Biochem Soc Trans 19:272-275.

Kozawa O, Tokuda H, Miwa M, Kotoyori J, Oiso Y (1992) Crosstalk regulation between cyclic AMP production and phosphoinositide hydrolysis induced by prostaglandin $\mathrm{E}_{2}$ in osteoblast-like cells. Exp Cell Res 198:130-134.

Kurahashi T, Shibuya T (1990) $\mathrm{Ca}^{2+}$-dependent adaptive properties in the solitary olfactory receptor cell of the newt. Brain Res 515:261268.

Leveteau J, Andriason I, Trotier D, MacLeod P (1989) Role of divalent cations in EOG generation. Chem Senses 14:611-620.

Lowry OH, Rosebrough NJ, Farr AL, Randall RJ (1951) Protein measurement with the folin reagent. J Biol Chem 193:265-275.

Ludwig J, Marglit T, Eismann E, Lancet D, Kaupp B (1990) Primary structure of a CAMP-gated channel from bovine olfactory epithelium. FEBS Lett 270:24-29.

Morris GM, Hadcock JR, Malbon CC (1991) Cross-regulation between G-protein-coupled receptors. J Biol Chem 266:2233-2238.

Nakamura T, Gold GH (1987) A cyclic-nucleotide gated conductance in olfactory receptor cilia. Nature 325:442-444.

Pace U, Hanski E, Saloman Y, Lancet D (1985) Odorant-sensitive adenylate cyclase mediates olfactory reception. Nature 316:225-228.

Parenti M, Ceresoli G, Consolo S, Groppetti A (1989) Cross-talk between different intracellular signalling pathways in the rat hippocampus. Cell Biol Int Rep 13:1177-1187.

Restrepo D, Miyamoto T, Bryant BP, Teeter JH (1990) Odor stimuli trigger influx of calcium into olfactory neurons of the channel catfish. Science 249:1166-1168.

Ronnett GV, Hester LD, Snyder SH (1991a) Primary culture of neonatal rat olfactory neurons. J Neurosci 11:1243-1255.

Ronnett GV, Parfilt DJ, Hester LD, Snyder SH (1991b) Odorantsensitive adenylate cyclase: rapid potent activation and desensitization in primary olfactory neuronal cultures. Proc Natl Acad Sci USA 88:2366-2369.

Salomon Y (1979) Adenylate cyclase assay. Adv Cyclic Nucleotide Res 10:31-54.

Sklar PB, Anholt RRH, Snyder SH (1986) The odorant-sensitive adenylate cyclase of olfactory receptor neurons. J Biol Chem 261:1553815543.

Winegar BW, Rosick ER, Schafer R (1988) Calcium and olfactory transduction. Comp Biochem Physiol [A] 91:309-351. 